\title{
Jurnal Delima Harapan 2021
}

\section{PENGARUH PENDIDIKAN KESEHATAN DENGAN BOOKLET TERHADAP PENGETAHUAN IBU HAMIL TENTANG 1000 HARI PERTAMA KEHIDUPAN}

\author{
Lilis Susanti \\ Fakultas Ilmu Kesehatan Program Studi D III Kebidanan IKesT Muhammadiyah Palembang \\ Email :lilissusanti_29@yahoo.co.id
}

\begin{abstract}
Nutritional problems often arise because people have inadequate knowledge, beliefs, values or norms. Eating a nutritious diet is an important behavior for a child's health and development. However, there are several factors that affect balanced maternal eating, including knowledge, so to increase mother's knowledge with health education Health education delivered with booklets can increase the knowledge of pregnant women about the first 1000 days of life. The purpose of the study was to determine the effect of health education with booklets on the knowledge of pregnant women about the first 1000 days of life. This research is a quantitative research with a quasi-experimental method. The design used in this study was a pre-post test with control group design. Kontrol). Sampling in this research using non-random sampling technique purposive sample type. Several pregnant women who did a pregnancy check-up in January - May 2020 at BPM Herasdiana and met the sample inclusion criteria as many as 30 pregnant women respondents who were divided into 2 groups, namely 15 pregnant women who were treated using bookle media (intervention group) and 15 pregnant women not given a bookle (group). The statistical test Wilcoxon test results The results showed that there was a significant difference in increasing knowledge about the first 1000 days of life between the group that was given the booklet and the group that was not given the booklet (control) with $p<0.05$. The role of midwives as professionals is indispensable in providing information and education to increase mother's knowledge about the first 1000 days of life, starting from couples of childbearing age to preparing for pregnancy, pregnant women and breastfeeding mothers.
\end{abstract}

Keywords: 1000 days of life, pregnant mothe, booklet,knowledge.

\section{PENDAHULUAN}

Masalah gizi seringkali muncul karena masyarakat memiliki pengetahuan, kepercayaan, nilai atau norma yang kurang memadai. makan makanan yang bergizi merupakan perilaku yang penting untuk kesehatan dan perkembangan anak. Lebih dari sepertiga kematian bayi dan anak, serta $11 \%$ beban penyakit di dunia disebabkan karena kekurangan gizi pada ibu hamil dan anak. bukan hanya itu, kekurangan gizi pada ibu hamil dapat nantinya mengganggu perkembangan fisik, mental dan kecerdasan anak. (Modul kesehaan dan gizi 2018).

Upaya peningkatan status gizi untuk pembangunan sumber daya manusia berkualitas pada hakikatnya harus dimulai sedini mungkin, yaitu dimulai dari masa kehidupan janin. Hal ini menjadi penting karena dapat menunjang tumbuh kembang serta perbaikan gizi. Salah satu hal yang dapat dilakukan untuk perbaikan gizi adalah pemenuhan gizi seimbang pada masa seribu hari pertama. Di Indonesia disebut dengan Gerakan Nasional Sadar Gizi dalam Rangka Percepatan Perbaikan Gizi Pada 1000 Hari Pertama Kehidupan (Gerakan 1000 Hari Pertama Kehidupan dan disingkat Gerakan 1000 HPK).

Seribu hari pertama kehidupan (1000 HPK) adalah fase kehidupan yang dimulai sejak terbentuknya janin dalam kandungan (270 hari) sampai berusia 2 tahun (730 hari). Periode ini disebut dengan periode emas (golden periode), yang jika tidak dimanfaatkan 


\section{Jurnal Delima Harapan $\mid 2021$}

dengan baik akan terjadi kerusakan yang bersifat permanen (window of opportunity

Perbaikan gizi pada kelompok seribu hari pertama kehidupan akan menunjang proses tumbuh kembang dari masa kehamilan hingga anak usia 2 tahun (Bappenas, 2012: 6). Pada 1000 hari pertama kehidupan, fokus penanganan masalah gizi adalah dengan menurunkan proporsi anak balita pendek (stunted), anak balita kurus (wasted), anak yang lahir berat badan rendah dan gizi lebih pada anak, serta menurunkan proporsi anemia wanita usia subur dan meningkatkan prosentase ASI eksklusif. Apabila pada periode emas ini zat gizi tidak terpenuhi dengan baik, maka akan muncul masalah- masalah gizi tersebut (Bappenas 2012). Indonesia merupakan salah satu Negara dengan prevalensi stunting cukup tinggi. Berdasarkan data Riskesdas tahun 2018 didapatkan prevalensi stunting pada balita 30,8.\% menurun jika dibandingkan dengan data Riskesdas tahun 2013 yaitu 37,2\%. Sedangkan Provinsi Sumatera Selatan sejak ahun 2018 dan 21019 angka stunting dan gizi buruk mengalami penurunan pada tahun 2018 persentasi stunting melebihi persenasi nasional $31 \%$ unuk gizi buruk $0.04 \%$ unuk tahun 2019 persentasi stunting $28.98 \%$ dan gizi buruk $0.02 \%$ (SSGBI).

Konsumsi gizi yang baik dan seimbang sangat berpengaruh terhadap status gizi seseorang yang merupakan modal utama bagi kesehatan individu. Konsumsi gizi yang salah atau tidak sesuai dengan aturan akan menyebabkan masalah kesehatan. Pemenuhan kebutuhan gizi akan berdampak pada status kesehatan seseorang, dan status kesehatan akan berdampak pada status gizi seseorang). Ibu hamil, ibu menyusui, bayi baru lahir dan anak usia di bawah dua tahun (baduta) merupakan kelompok sasaran untuk meningkatkan kualitas kesehatan pada 1000 hari pertama kehidupan manusia. Kelompok sasaran ini merupakan kelompok rentan terhadap gizi (Hariyani, 2011).
Pada pemenuhan gizi seorang balita ibu memegang peranan yang sangat penting. Ibu merupakan orang yang paling dekat dengan anak, orang pertama yang berhubungan dengan anak, dan yang memberikan alokasi waktu lebih banyak dalam pengasuhan anak. Sikap merupakan faktor yang memengaruhi perilaku kesehatan seseorang. Perubahan sikap secara berkelanjutan dapat memengaruhi perilaku seseorang, Perilaku pemenuhan gizi yang baik dapat meningkatkan status gizi anak (Apooh, Yaa, \& Krekling, 2005). Status gizi adalah keadaan tubuh sebagai akibat konsumsi makanan dan penggunaan zat-zat gizi. Keadaan tersebut dapat dibedakan dengan status gizi kurang, baik, dan lebih (Almatsier, 2001).

Penelitian ini bertujuan untuk mengetahui pengaruh pendidikan kesehatan dengan booklet terhadap pengetahuan ibu hamil tentang 1000 hari pertama kehidupan.

\section{METODE PENELITIAN}

Penelitian ini merupakan penelitian kuantitatif dengan metode quasi experiment. Desain yang digunakan dalam penelitian ini adalah pre-post test with control group design, Pengambilan sampel dalam penilitian ini menggunakan teknik non-random sampling jenis purposive sample. Sampel dalam penelitian ini adalah sebagian ibu hamil yang melakukan pemeriksaan hamil pada bulan Januari - Mei 2020 di BPM Herasdiana Kota Palembang yang memenuhi kriteria inklusi.

Besar sampel yang digunakan dalam penelitian dengan metode eksperimen. sampel sebesar 30 responde yang dibagi menjadi 2 kelompok yaitu 15 ibu hamil yang diberi perlakuan menggunakan media bookle tentang 1000 hari pertama kehidupan (kelompok intervensi) dan 15 ibu hamil tidak diberi bookle tentang 1000 hari pertama kehidupan (kelompok Kontrol).

Adapun kriteria inklusi sebagai berikut:

a. Ibu hamil trimester I, II dan III

b. Ibu bisa membaca dan menulis 


\section{Jurnal Delima Harapan $\mid 2021$}

c. Ibu bersedia mengisi kuesioner pretest dan post test

d. Bertempat tinggal di wilayah kerja PMB Herasdiana

Adapun Kriteria Eksklusi yaitu:

a. Ibu hamil yang tidak bisa membaca dan menulis

b. Ibu ibu hamil yang tidak bersedia menjadi responden

Responden yang bersedia ikut serta dalam penelitian dengan menandatangani formulir informed consent, Kemudian peneliti memberikan kuesioner pretest tentang 1000 hari pertama kehidupan kepada reponden untuk mengisi semua kuesioner dalam waktu 30. Setelah pretest selesai dikerjakan, ibu hamil pada kelompok perlakuanakan diberikan booklet tentang 1000 hari pertama kehidupan. yang meliputi pengertian, tujuan, dan manfaat dari 1000 hari pertama kehidupan kepada ibu hamil, ibu menusyui dan balita Sedangkan responden pada kelompok control tidak diberikan booklet. Kuesioner pretest dan posttest merupakan kuesioner yang sama dan dikerjakan dalam waktu 30 menit.

\section{HASIL DAN PEMBAHASAN}

Penelitian telah dilakukan terhadap 30 responden yang memenuhi kriteria inklusi dan ekslusi yang terdiri dari dua kelompok. Kelompok perlakuan merupakan 15 responden yang diberikan booklet tentang 1000 hari pertama kehidupan sedangkan kelompok kontrol merupakan 15 responden yang tidak diberikan booklet tentang 1000 hari pertama kehidupan.

Hasil pengaruh pendidikan kesehatan menggunakan booklet terhadap pengetahuan ibu hamil tentang 1000 hari pertama kehidupan.

a. Karakteristik Responden Pada Kedua Kelompok Penelitian

Tabel 1 Karakteristik Responden Pada Kedua Kelompok Penelitian

\begin{tabular}{lcccc}
\hline \multirow{2}{*}{ Karakteristik } & \multicolumn{4}{c}{ Kelompok kontrol $\begin{array}{c}\text { Kelompok } \\
\text { Intervensi }\end{array}$} \\
\cline { 2 - 5 } \multicolumn{1}{c}{ Responden } & \multicolumn{5}{c}{ jumlah } & jumlah & $\%$ \\
\hline Umur & & & & \\
$<20$ tahun & 0 & 0 & & \\
20-30 tahun & 13 & 86.7 & 11 & 73.3 \\
$>30$ tahun & 2 & 13.3 & 4 & 26.7 \\
Pendidikan & & & & \\
SD & 4 & 26.7 & 2 & 13.3 \\
SMP & 5 & 33.3 & 5 & 33.3 \\
SMA & 5 & $33 . .3$ & 5 & 33.3 \\
PT & 1 & 6.7 & 3 & 20.0
\end{tabular}

\section{Pekerjaan}

$\begin{array}{lcccc}\text { Tidak bekerja } & 14 & 93.3 & 10 & 66.7 \\ \text { Bekerja } & 1 & 6.7 & 5 & 33.3\end{array}$

Dari kedua kelompok, mayoritas responden berada pada usia produktif $(20-30$ tahun) sebanyak 13 responden (86.7\%). Menurut Huclock (1998), semakin cukup umur, tingkat kematangan dan kekuatan seseorang akan lebih matang dalam berfikir dan bekerja sehingga masih dapat menyerap informasi sebanyak- banyaknya. Umur berpengaruh dalam proses belajar menyesuaikan diri, seiring dengan bertambahnya umur seseorang maka semakin banyak pengalaman yang akan didapat dari lingkungan dalam membentuk perilakunya (Notoadmodjo, 2003).

Pendidikan ibu berdasarkan dengan hasil penelitian menunjukkan, Pendidikan terakhir responden yang sampai perguruan tinggi sangat sedikit yaitu 1 responden $(6.7 \%)$ pada kelompok kontrol dan 3 responden (20.0 \%) pada kelompok intervensi). Semakin rendah tingkat pendidikan ibu, maka kemungkinan sulit bagi mereka untuk menangkap informasi maupun ideide termasuk tentang pengetahuan pemenuhan gizi pada anak 1000 hari pertama kehidupan/ Golden Perioed. Manusia membutuhkan pendidikan dalam kehidupannya. Tingkat pendidikan yang 
tinggi akan menambah pengetahuan yang dimiliki serta dapat membentuk suatu perilaku yang baik pula, termasuk di dalamnya berperilaku kesehatan (Aritama, 2000).

Pekerjaan ibu berdasarkan dengan hasil penelitian menunjukkan menggambarkan mayoritas responden tidak bekerja. Jumlah responden yang tidak bekerja yaitu sebanyak 14 responden (93.3\%) pada kelompok kontrol dan sebanyak 10 responden (66.7 \%) pada kelompok intervensi. Hasil ini menunjukkan bahwa sebagian ibu memiliki waktu yang lebih banyak untuk mengasuh dan merawat anaknya karena ibu tidak bekerja diluar rumah untuk mancari nafkah. Namun hal ini harus diimbangi dengan pengetahuan dan pendidikan ibu dalam mendapakan informasi pemberian makanan yang baik dan bergizi pada anak balitanya tentang pemenuhan gizi pada anak 1000 hari pertama kehidupan. Berkembangnya berbagai media cetak maupun elektronika semakin kuat untuk memudahkan ibu mendapatkan berbagaikan informasi khususnya tentang pemenuhan gizi pada anak 1000 hari pertama kehidupan.

Tabel 2. Rata-Rata Skor Pengetahuan Responden pada Kelompok Kontrol dan Intervensi

\begin{tabular}{|c|c|c|c|c|c|c|c|c|}
\hline & & Pre-test & & & & & & \\
\hline Baik & & & ang & Baik & & Baik & & Kurang Baik \\
\hline & $\mathrm{n}$ & (persen) & $\mathrm{n}$ & (persen) & $\mathrm{n}$ & (persen) & $\mathrm{n}$ & (persen) \\
\hline & & $\%$ & & $\%$ & & $\%$ & & $\%$ \\
\hline Kelompok & 8 & 53.3 & 7 & 46.7 & 8 & 53.3 & 7 & 46.7 \\
\hline Kontrol & & & & & & & & \\
\hline $\begin{array}{l}\text { Kelompok } \\
\text { Intervensi }\end{array}$ & 7 & 46.7 & 8 & 53.3 & 10 & 67.0 & 5 & 33,0 \\
\hline
\end{tabular}

Jumlah responden dengan pengetahuan baik menunjukkan adanya peningkatan pada kelompok intervensi. Pada saat pre-test jumlah responden yang berpengetahuan baik sebanyak 7 responden $(46.7 \%)$ dan jumlah responden yang berpengetahuan kurang baik sebanyak 8 responden $(53.3 \%)$. Kemudian pada saat posttest jumlah responden yang berpengetahuan baik sebanyak 10 responden $(6.7 .0 \%)$ dan jumlah dan jumlah responden yang berpengetahuan kurang baik sebanyak 5 responden $(33,0)$.

Hasil ini berbeda pada kelompok kontrol yang menunjukkan tidak ada peningkatan jumlah responden yang berpengetahuan baik. Pada saat pre-test jumlah responden yang berpengetahuan baik sebanyak 8 responden
(53.3 \%) dan jumlah responden yang berpengetahuan kurang baik sebanyak 7 responden $(46.7 \%)$. Kemudian pada saat posttest jumlah responden yang berpengetahuan baik sebanyak 8 responden $(53.3 \%)$ dan jumlah responden yang berpengetahuan kurang baik sebanyak 7 responden $(46.7 \%$ ).

Analisis Beda Rerata nilai pengetahuan responden saat post-test pada kedua kelompok kelompok intervensi dan kelompok Kontrol.

Tabel 3. Analisa Beda Rerata Skor 


\section{Jurnal Delima Harapan 2021}

Pengetahuan Responden Saat PostTest Pada Kedua Kelompok $(\mathrm{n}=30)$

\begin{tabular}{|c|c|c|}
\hline $\begin{array}{l}\text { Nilai pengetahuan } \\
\text { Intervensi }\end{array}$ & $\begin{array}{l}\text { Mean rank } \\
20.23\end{array}$ & Nilai $p$ \\
\hline Kontrol & 10.77 & 0.001 \\
\hline
\end{tabular}

Hasil analisa uji Mann Whitney pada skor pengetahuan post-test antara kelompok intervensi dan kelompok kontrol menunjukkan dengan nilai $p=0.001 \quad(<0.05)$ artinya ada perbedaan pengetahuan yang signifikan antara kedua kelompok saat posttest.

Pengetahuan atau kognitif merupakan domain yang sangat penting dalam membentuk tindakan seseorang (oventbehavior ). Masalah gizi seringkali muncul karena masyarakat memiliki pengetahuan, kepercayaan, nilai atau norma yang kurang memadai. contoh umum di masyarakat adalah mentolerir ibu hamil makan dengan porsi yang jauh lebih sedikit (dibanding masa sebelum hamil), memberi pisang, air atau makanan padat lainnya pada anak usia di bawah 6 bulan. Agar anak menjadi pintar dan tumbuh optimum, keluarga perlu memperhatikan masa penting, yakni 1000 hari Pertama kehidupan mulai selama kehamilan (9 bulan atau 270 hari) sampai 2 tahun pertama sejak anak dilahirkan (730 hari pertama). seribu hari pertama merupakan periode penting di mana gangguan yang muncul pada masa ini akan berakibat secara menetap dan tidak dapat diperbaiki. Pendidikan kesehatan dapat menggunakan berbagai media, salah satunya adalah melalui penggunaan booklet..

Pada Tabel 3 menunjukkan terdapat perbedaan yang bermakna pada peningkatan pengetahuan tentang 1000 hari Pertama kehidupan antara kelompok yang diberikan booklet (perlakuan) dan kelompok yang tidak diberikan booklet (kontrol) dengan nilai $p<0,05$.

Jumlah responden dengan pengetahuan baik menunjukkan adanya peningkatan pada kelompok intervensi. sebelum dan setelah diberikan booklet yaitu Pada saat pre-test jumlah responden yang berpengetahuan baik sebanyak 7 responden $(46.7 \%)$ dan jumlah responden yang berpengetahuan kurang baik sebanyak 8 responden $(53.3 \%)$. Kemudian pada saat posttest jumlah responden yang berpengetahuan baik sebanyak 10 responden $(67.0 \%)$ Hasil ini berbeda pada kelompok control (tidak diberikan booklet yang menunjukkan tidak ada peningkatan jumlah responden yang berpengetahuan baik. Pada saat pre-test jumlah responden yang berpengetahuan baik sebanyak 8 responden $(53.3 \%)$ dan jumlah responden yang berpengetahuan kurang baik sebanyak 7 responden $(46.7 \%)$. Kemudian pada saat posttest jumlah responden yang berpengetahuan baik sebanyak 8 responden $(53.3 \%)$ dan jumlah responden yang berpengetahuan kurang baik sebanyak 7 responden $(46.7 \%)$.

Pada kelompok yang kontrol (tidak diberikan booklet) tidak terjadinya peningkayan nilai post test. Hal ini dapat terjadi karena pada kelompok kontrol tidak dilakukan penyampaian informasi seperti pada kelompok perlakuan, sehingga responden tidak mendapatkan informasi yang benar tentang 1000 hari Pertama kehidupa, hal ini berpengaruh terhadap pengisian kuesioner. Sedangkan pada kelompok perlakuan, responden mendapatkan informasi yang lengkap tentang 1000 hari Pertama kehidupan melalui media booklet.

Booklet adalah buku tipis yang mudah dibawa, memuat informasi yang lengkap, jelas, mudah dimengerti, berisi tulisan dan gambar.(Agustin et al., 2014) Booklet yang diberikan pada kelompok perlakuan berisi tentang informasi yang lengkap ttentang 1000 hari Pertama kehidupan mencakup pengertian, tujuan pemberian gizi pada tentang 1000 hari Pertama kehidupan , manfaat dari gizi, dampak dari kurang gizi pada 1000 hari Pertama kehidupan pada anak dan contoh makan makanan yang beraneka ragam yang mengandung karbohidrat, protein hewani, protein nabati, sayur, dan buah-buahan yang mengandung gizi tinggi penting bagi ibu hamil dan menyusui, serta cara mengelolah sayur dan membuat makanan bayi yang baik dan sehat. 


\section{Jurnal Delima Harapan 2021}

\section{(Modul PKH)}

Pengetahuan seseorang dapat meningkat disebabkan penyerapan informasi yang baik semakin tinggi tingkat pengetahuan dan pemahaman terhadap kesehatan, akan meningkat pula cara pandang terhadap konsep sehat dan sakit menjadi mantap yang pada akhirnya akan mempengaruhi pandangan, cara hidup dan upaya seseorang untuk dapat menigkatkan derajat kesehatan. Secara teori semakin tinggi tingkat pendidikan individu maka semakin mudah mendapatkan informasi dan tingkat pengetahuan seseorang semakin baik (Arikunto, 2006).

Hasil penelitian ini sejalan dengan penelitian sebelumnya dimana pendidikan kesehatan yang disampaikan dengan media booklet dapat berpengaruh signifikan dalam meningkatkan pengetahuan. Pengetahuan yang baik perlahan-lahan akan membentuk perilaku yang positif sehingga pemilihan pendidikan yang efektif diperlukan untuk mencapai tujuan yang maksimal.(Ma'munah, 2015).

Booklet adalah media komunikasi massa yang bertujuan untuk menyampaikan pesan yang bersifat promosi, anjuran larangan- larangan kepada khalayak massa, bentuk buku, baik tulisan maupun gambar. Sehingga akhir dari tujuannya tersebut adalah agar masyarakat yang sebagai obyek memahami dan menuruti pesan yang terkandung dalam media komunikasi massa tersebut (Machfoedz \& Suryani, 2007).

Penelitian ini juga sejalan dengan penelitian sebelumnya dimana media booklet dapat meningkatkan pengetahuan tentang pengaruh pendidikan kesehatan terhadap pengetahuan nutrisi ibu. Informasi dan pengalama pribadi merupakan faktor yang mempengaruhi pengetahuan. Berkembangnya teknologi akan menyediakan berbagai media yang dapat mempengaruhi pengetahuan masyarakat.( Ma'munah, 2015)

\section{KESIMPULAN}

Berdasarkan hasil penelitian didapatkan bahwa terdapat perbedaan yang bermakna pada peningkatan pengetahuan tentang 1000 hari pertama kehidupan antara kelompok yang diberikan booklet (perlakuan) dan kelompok yang tidak diberikan booklet (kontrol)dengan nilai $\mathrm{p}<0,05$.

\section{SARAN}

Peran bidan sebagai tenaga profesional sangat diperlukan dalam memberikan informasi dan edukasi untuk meningkatkan pengetahuan ibu tentang 1000 hari pertama kehidupan, mulai dari pasangan usia subur hingga persiapan kehamilan, ibu hamil dan ibu menyusui.

\section{REFERENSI}

Agustin, M., KEP, I. S., NS, M., Susilaningsih, E. Z. \& KP, S. 2014. Efektifitas Pendidikan Kesehatan Media Booklet Dibandingkan Audiovisual Terhadap Pengetahuan Orang Tua Tentang Karies Gigi Pada Anak Usia 5-9 Tahun Di Desa Makamhaji. Universitas Muhammadiyah Surakarta.

Almatsier, Sunita. (2009). Prinsip Dasar Ilmu Gizi. Jakarta: Gramedi.

Arikunto, S. 2010. Manajemen Penelitian. Rineka Cipta.

Artini, F. R., Maliya, A. \& Sudaryanto, A. 2014. Perbedaan Pengaruh Pendidikan Kesehatan Menggunakan Media Leaflet dengan Booklet terhadap Tingkat Pengetahuan Masyarakat tentang Chikungunya di Desa.

Behrman, E Richard (Editor). 2007. Ilmu Kesehatan Anak Nelson Vol. 1. Jakarta: EGC.

Brown, Judith E. 2011. Nutrition Through the Life Cycle International Edition.

Bappenas, Kementerian Kesehatan, Kementerian Sosial, Tim Nasional Percepatan 


\section{Jurnal Delima Harapan 2021}

Penanggulangan Kemiskinan

(TNP2K), dan UNICEF. 2014. Buku

Panduan Pendamping PKH dalam

Sesi Pertemuan Bulanan Kelompok

PKH. Jakarta

Bappenas, Kementerian Kesehatan, Kementerian

Sosial,Modul kesehata dan gizi 2018.

Pertemuan peningkatan kemampuan

keluarga (P2k2), program keluarga

harapan $(\mathrm{PKH})$

Endres, Jeannette Brakhane. 2004. Food,

Nutrition, and The Young Child Fifth

Edition. New Jersey: PEARSON

Merril Prentice Hall.

Farudin, Ahmad. 2011. Perbedaan Efek

Konseling Gizi Dengan Media

Leaflet Dan Booklet Terhadap

Tingkat Pengetahuan, Asupan Energi

Dan Kadar G Gula Darah Pada

Pasien Diabetes Melitus Di Rsud Dr.

Moewardi Surakarta. Tesis

Universitas Sebelas Maret Surakarta

Indonesia, K. K. R. 2014. Profil Kesehatan

Indonesia 2013. Jakarta:

Kementerian Kesehatan Republik

Indonesia

Ma'munah, M. 2015. Pengaruh Pendidikan

Kesehatan Dengan Booklet Terhadap

Pengetahuan Ibu Laktasi Di Wilayah

Kerja Puskesmas Ciputat Timur. UIN

Syarif Hidayatullah Jakarta: Fakultas

Kedokteran Dan Ilmu Kesehatan, 2015.

Notoatmodjo, S. 2010. Ilmu perilaku kesehatan. Jakarta: rineka cipta, 200, 26-35.

Organization, W. H. 2009. Infant and young child feeding: model chapter for textbooks for medical students and allied health professionals.

Rahmat Yudi. Balit di sumsel stuning dan gizi buruk, 5 agusus 2020, hps://infopublik.id

Swarjana, I Ketut 2012. Metodologi penelitian kesehata. Yogyakarta: A 